\title{
Evolving an ethical framework for Covid-19 management in India
}

\author{
SAURAV BASU, NANDINI SHARMA
}

\section{Abstract}

The Covid-19 pandemic has caused millions of cases and deaths worldwide and has caused a massive global economic contraction. Governments, policymakers, and medical professionals have been confronted with several complex bioethical dilemmas during these exceptional circumstances. In developing countries like India, having a large population base, inadequate preexisting public health infrastructure, and a multi-level government system with complex administrative mechanisms imposes enormous barriers and challenges in the effective and ethical management of the pandemic. Furthermore, endemic corruption, limited bureaucratic and organisational accountability, and weak oversight, especially among stakeholders in the vast private and non-government health and allied services sector, complicate the assessment of their adherence to ethical public health practices.

All this constitutes a moral imperative for practitioners of medical ethics in India to develop a framework for ethical preparedness during a pandemic. Failure to do so runs the grave risk of moral and ethical chaos from ad-hoc decision making that is deprived of ethical guidance when confronted with an unprecedented public health crisis. In this narrative, we provide some of the building blocks for a comprehensive ethical framework for decision making and shaping public health responses to pandemic situations and associated challenges.

Key words: Covid-19; ethical framework; public health; pandemic preparedness; pandemic ethics

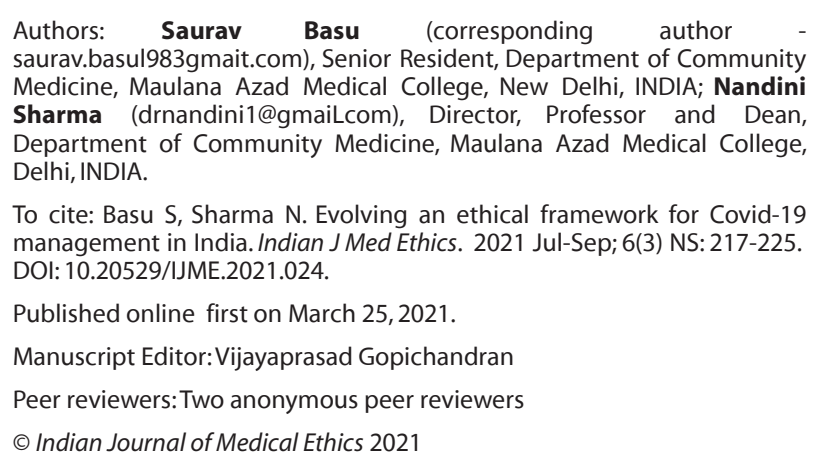

To cite: Basu S, Sharma N. Evolving an ethical framework for Covid-19 management in India. Indian J Med Ethics. 2021 Jul-Sep; 6(3) NS: 217-225. DOI: 10.20529/IJME.2021.024.

Published online first on March 25, 2021.

Manuscript Editor:Vijayaprasad Gopichandran

Peer reviewers: Two anonymous peer reviewers

(c) Indian Journal of Medical Ethics 2021

\section{Background}

The Covid-19 pandemic, has been recognised by the World Health Organization (WHO) as the most severe global health emergency ever reported by the organisation. India has recorded the second-highest global Covid-19 burden in terms of absolute case numbers and surpassed 100,000 deaths to date, despite a high recovery and a low case fatality rate (1).

Data from population-based seroepidemiological studies and emerging reports of reinfection indicate that the attainment of natural herd immunity against Covid-19 is unlikely and achieving vaccine induced herd immunity will require substantial time and resources, especially in the low and middle-income countries (LMICs) (2). Major challenges experienced during the pandemic included the surge in demand for critical care resources which exceeded their availability, either due to overwhelming increases in cases or due to the pre-existing weak public health infrastructure (3). Furthermore, sustained resource provision for maintaining continuity of care for the millions of existing patients and beneficiaries of other health conditions is another major challenge during the crisis. The administration and the government occasionally had to rely on arguably authoritarian and draconian measures that violated individual autonomy for containing the spread of infection. Under these unprecedented circumstances, governments, policymakers, and physicians are also confronted with the need to make complicated decisions to allocate scarce resources, while upholding the principles of public health and biomedical ethics (4). However, India's pandemic management strategy has neglected venturing into any critical ethical inquiry until recently.

Ethics preparedness is the public health system's capacity for protecting population health and developing the ability for enabling rapid healthcare system responsiveness. This must be based on an ethical framework built on trust, human dignity and equal moral worth of individuals when confronted with health emergencies (5-7). Although India has successfully contained several epidemics in the past, including H1N1, Nipah, Avian influenza, etc, it lacks any preexisting ethical framework for guidance in strategic decision making during pandemics.

Globally, pandemic ethics has reflected tensions arising from 
the failure of consensus-building towards the most effective means for controlling the pandemic, reducing the loss of lives, and minimising the negative economic impact on the community (8). In the Indian context, the health, sanitation, and housing systems' preexisting vulnerability, high burden of comorbidities, widespread nutritional deprivation, and the global economic downturn further increase the population's susceptibility to a pandemic (9). The responsibility of adhering to ethical principles during pandemic planning and responses is vital to preserve public health, protect human rights, build trust and demonstrate a commitment to fairness and equity. Here, we explore the processes for building a comprehensive ethical framework for decision making and shaping public health responses to future pandemic situations.

\section{An ethical pandemic framework for India through a value-based approach}

We considered an ethical framework based on values that were either substantive or procedural when realised through appropriate outcomes and processes, respectively. The substantive values include individual liberty, protection of the public from harm, proportionality, (maintaining) privacy, duty to provide care, reciprocity, equity, trust, solidarity, and stewardship. The procedural values include being reasonable, open and transparent, inclusiveness, responsiveness, and accountability $(7,10)$. Xafis et al (2019) and Dawson and Jennings (2012) have previously recommended that legitimate, ethical inquiry in an ethical framework should not prioritise one value over another and instead strive to attain a balanced outlook in advocating solutions $(11,12)$. Moreover, evaluating and recommending actions based on an ethical framework engenders a complex process of negotiation wherein invariably, certain values are privileged while others are compromised, even if not violated (12). In this regard, the principles suggested by Upshur (2002) are applied to assess the justifiability of public health interventions, which include:

\section{- Doing no harm}

Based on the classic principle of John Stuart Mill (14), exercising state power to restrict the liberty of individuals is ethically justifiable only when the objective is to prevent harm to others.

\section{- Using the least restrictive or coercive means}

The state has a monopoly on the application of coercive power to achieve public health goals. Nevertheless, only use of the minimum coercive power required to achieve those goals, in exceptional circumstances, is justified, and should be preceded by the utmost application of persuasion through educative means.

- Reciprocity:

Individuals and communities at the vanguard of the public health action during the pandemic facing a higher risk of infection must be adequately empowered and supported for effective discharge of their duties.

- Transparency.

Transparency requires all legitimate stakeholders to be involved in the decision-making process and freely provide inputs for deliberations with minimal political interference or administrative or state coercion.(13)

\section{Pandemic challenges and responses: achieving ethical propriety}

We delineate below the steps required towards evolving an ethical framework applicable in the Indian context to pandemic management, from a value-based and public health perspective. They include: ethical distribution of scarce health resources, healthcare service delivery and coverage of non-Covid-19 related health conditions, upholding the rights and obligations of frontline healthcare workers, applicability of coercion to inhibit the spread of infection, balancing health and economic objectives, and achieving political synergy for combating the pandemic within a multi-party and multi-level government system.

\section{(i) Rationing and allocation of scarce healthcare resources}

Public health resources for managing the Covid-19 pandemic were scarce due to high demand, which could include testing and diagnostic facilities, human resources, and hospital beds especially ventilator beds (15). Consequently, ethical allocation of these resources should be based on the principles of justice and equity.

Although health is a state subject according to the Indian constitution, the central government has overarching powers for health-related spending, framing health policy, and issuing directives to states during outbreaks and pandemics vide the Epidemic Diseases Act, 1897, and the Disaster Management Act, 2005. Here, we have used the word "government" interchangeably, for both governments unless explicitly specified.

(a) Covid-19 testing strategy protocols : The evolution of the Covid-19 testing protocol in India reflected a dynamic testing strategy that progressively expanded the eligibility pool for testing with simultaneous accelerated expansion in the overall testing capacity with quality assurance. Linking of testing with a countrywide government funded universal health insurance scheme accorded protection for the most vulnerable populations' (16). These interventions upheld substantive ethical values of equity, and duty to provide care, and also the procedural values of responsiveness and accountability.

The government policy of extensive deployment of the Rapid Antigen Test (RAT) since June 2020 to enable mass testing and prompt treatment was validated by the WHO policy guidance note issued in September 2020, advocating the promotion of high-quality rapid diagnostic tests for 
LMICs $(17,18)$. However, there were concerns with the high false-negative rate associated with the test and the lack of follow-up RT-PCR testing in a large proportion of symptomatic negative individuals (19). False-negative results would instill a false sense of security in individuals and continue the spread of infection violating the ethical principles of non-maleficence and justice. Furthermore, any suboptimal testing performance at the individual districts and states would entail failure of public health intervention, injustice, and inability to protect the people's health.

\section{(b) Allocation of hospital beds and triage}

It was well-established at the onset of the pandemic that a significant proportion of Covid-19 patients were likely to require hospitalisation and access to critical care services (15). In such emergencies, the number of individuals with life-threatening conditions exceeds the number that can be treated with the available resources simultaneously. Hence, triage is recommended for the reasonable allocation of scarce treatment resources. Doctors, thereby, have to prioritise treatment of patients with a higher probability of survival based on specific pre-established prognostic criteria, instead of the usual "first come first served" approach (20).

Early in the pandemic, mechanical ventilation was construed as the "toughest triage" since its initiation or termination during Covid-19 was considered to represent an absolute life or death alternative (21). In response to this crisis, the central government interventions focused predominantly on augmenting the supply of ventilators. India's pre-pandemic resources were sparse, with only 0.55 beds per 1000 population and a total of 57,000 ventilator-equipped beds, with significant regional disparity $(22,23)$. To address this critical shortfall, a total of 50,000 "made in India" ventilators were planned to be allotted to hospitals across the country through the special fund, PM-CARES, created for combating the Covid-19 pandemic (24). However, concerns were raised regarding the inexperience of some of the ventilator manufacturers given contracts and the clinical failure of some models due to inadequate quality controls (25). There has also been growing awareness that most hospitalised Covid-19 patients did not require ventilator support, and the expected demand was much smaller.

These actions reflect responsiveness on the part of the government, and despite a limited role in the current pandemic management, have potential long-term benefits for patients requiring emergency care services if the quality control issues are resolved satisfactorily as per expert opinion.

Overall, in our view, the government and administration across the country largely avoided the more ethically vexing challenges related to the scarce critical care resource allocation for pandemic triage. These included a failure to considering alternatives to conventional triage, especially when allocating lifesaving intensive care resources to multiple patients having similar prognosis and life expectancy in case of recovery. Globally, ethicists have struggled to reconcile the utilitarian, egalitarian, and social or instrumental value-based approaches towards pandemic triage that favour maximisation in terms of lives saved, social justice, and recognition of social utility, respectively $(8,26)$. In developing countries including India, the challenge and necessity for establishing an ethically robust pandemic triage model are even more acute, considering preexisting social inequalities based on socioeconomic, regional, and traditional inequities.

\section{(ii). Impact on health services and the health system}

Globally, existing health services and the performance of public health programmes have been negatively impacted by the Covid-19 pandemic due to the diversion of resources for pandemic containment (27). Governments are obliged to continue existing health services since most beneficiaries continue to depend on them, especially in a pandemic scenario, where private healthcare services are likely to be significantly less affordable and accessible. To balance the prioritising of pandemic management and maintain essential health services without neglecting either is difficult, especially during prolonged lockdown. Hence, working towards enhancing the capacity of the health system is the most desirable ethical course of action since an impoverished health system cannot meet the excess demands for withstanding a pandemic crisis.

Moreover, patients with multiple health conditions, including non-communicable diseases, tuberculosis, HIV-AIDS, undernourished and unimmunised children, are more susceptible to Covid-19 (15). The risk is further accentuated in poorly controlled chronic conditions resulting from medical nonadherence and interruption of treatment due to lack of access to drug refills (28). In India, the closure of general OPDs and routine laboratories in government hospitals undermined the essential medical and surgical needs of patients from weaker socioeconomic backgrounds (29). The primary healthcare system was also often unable to cope with the increased demand because of the limited preexisting infrastructural capacity and inadequate infection control measures (30).

Public health programmes are crucial for achieving several sustainable development goals through health system strengthening and the prevention, management, and control of several diseases of public health importance. During the pandemic, several national health programmes (NHPs) in India were adversely impacted both due to a decline in demand by clients due to fear of contracting Covid-19 and undermining of services resulting from the diversion of program-related health staff for Covid-19 containment activities. These disruptions are likely to contribute to higher morbidity, mortality, and a significant delay in achieving the objectives and goals of these NHPs (Table 1). 
Table 1. Characteristics of disruption of select national health programmes due to the Covid-19 pandemic in India

\begin{tabular}{|c|c|c|}
\hline National Health Programmes & Impact of Covid-19 & Health outcomes in patients and beneficiaries \\
\hline National TB Elimination Programme & $\begin{array}{l}\text { Reduction in case detection and } \\
\text { notification }\end{array}$ & $\begin{array}{l}\text { Increased TB-related mortality and morbidity } \\
\text { Delay in achieving TB elimination targets and goals (31) }\end{array}$ \\
\hline $\begin{array}{l}\text { National Programme for prevention } \\
\text { and control of NCDs, cancer, stroke and } \\
\text { CKD (32) }\end{array}$ & $\begin{array}{l}\text { Closure of private hospitals, } \\
\text { dialysis facilities, difficult in } \\
\text { accessing emergency care }\end{array}$ & $\begin{array}{l}\text { Medication non-adherence } \\
\text { Poor glycaemic control (28) High mortality rate in CKD5D patients (33) } \\
\text { Increased morbidity and mortality (28) } \\
\text { Increased out of pocket expenses }\end{array}$ \\
\hline Universal Immunisation Programme & $\begin{array}{l}\text { Delayed immunisation } \\
\text { Vaccine dropouts (missed doses) }\end{array}$ & $\begin{array}{l}\text { Reduced immunisation coverage } \\
\text { Outbreaks of vaccine preventable diseases especially measles (34) }\end{array}$ \\
\hline $\begin{array}{l}\text { Reproductive and maternal child } \\
\text { health programme }\end{array}$ & $\begin{array}{l}\text { Missed antenatal appointments } \\
\text { Dedicated Covid-19 hospitals } \\
\text { reducing access } \\
\text { Interruption in free menstrual } \\
\text { pad distribution in schools and } \\
\text { communities }\end{array}$ & $\begin{array}{l}\text { Increased out of pocket expenses for meeting antenatal and } \\
\text { institutional childbirth needs } \\
\text { Suboptimal menstrual hygiene in socioeconomically disadvantaged } \\
\text { adolescent girls and women (35) }\end{array}$ \\
\hline $\begin{array}{l}\text { Integrated Child Development Services } \\
\text { scheme }\end{array}$ & $\begin{array}{l}\text { Closure of anganwadis during } \\
\text { lockdown }\end{array}$ & $\begin{array}{l}\text { Hunger and undernutrition especially in pre-existing severely } \\
\text { undernourished children and pregnant women (36) }\end{array}$ \\
\hline
\end{tabular}

\section{(iii) Enforcement of coercive measures for controlling the} pandemic

The achievement of public health goals through involuntary and coercive measures entailing the diminishment of personal freedom and individual liberty are considered ethically appropriate only under the most compelling circumstances since they compromise autonomy, a fundamental principle of bioethics. Furthermore, regulations and legislations for ostensibly supporting public health measures can be abused by authoritarian governments for imposing punitive measures against political dissidents (37).

Nevertheless, there is growing evidence that authoritarian measures have had some success in controlling the Covid19 pandemic. In China, highly restrictive measures for enforcing isolation and quarantine enabled by the communist government have been effective in controlling the outbreak (38). In Hungary, the nationalist government has imposed emergency powers that decree prison terms for violating quarantine laws (39).

In India, early in the pandemic, privacy concerns had arisen from actions like ink-stamping of home quarantine labels or the occasional disclosure of patients' names with Covid-19 to ensure reporting by their contacts $(40,41)$. Compulsory hospitalisation of all persons diagnosed with Covid-19 also reflected an authoritarian stance of debatable beneficence that was later ameliorated through the option for home isolation of mild-cases. Some members of a large religious organisation linked to an initial single-source nationwide surge in cases were also arrested on charges of noncooperation and instigating violence against the police and authorities $(42,43)$. These measures indicate a progressive expansion of the state's coercive powers, correlating with an increasing threat of the spread of the coronavirus infection. However, the ethical legitimacy of incidents involving substantial coercion of citizens requires an in-depth analysis of individual acts and their social and health consequences to identify if the measures were essential to preserve public health or whether the state's coercive apparatus was overzealous in exercising its power.

\section{(iv) Healthcare professionals and their obligation to treat Covid-19 patients}

An emerging ethical concern was the compulsion of healthcare workers in several countries affected by the pandemic to work without adequate personal protective equipment (PPE). Thousands of doctors and nurses have lost their lives while battling Covid-19 globally. Gopichandran has alluded to this conundrum wherein the code of medical ethics makes explicit reference to the duty to care while remaining silent on the protection of the self (44). Nevertheless, the failure to provide adequate PPE to the 
healthcare personnel tending to presumptive or confirmed Covid-19 patients violates the principle of reciprocity and also undermines the public health justification that compels medical professionals with duty to care (45).

The initial shortage of PPE globally necessitated the formulation of guidelines that were conservative and whose directives did not coincide with the safety concerns of a significant proportion of HCWs. For instance, the WHO guidelines recommend only surgical masks for healthcare workers not involved in close contact and direct management or care of Covid-19 patients (46). However, the increasing burden of cases at hotspots and healthcare providers being compelled to work in small and crowded health facilities creates high-risk environments. Was it ethically unreasonable for HCWs to demand the best protection available for themselves, even if at variance with the scientific consensus? In the context of proportionality, considering the limited resources and armed with the scientific mandate, such misgivings of the HCWs can be rejected due to their presumed excessiveness (47). However, in terms of responsiveness and solidarity, India has not only achieved adequacy in indigenous manufacturing of PPE, including N-95 masks from nearly negligible production before the pandemic but has also been exporting the same globally (48).

A consequence of the Covid-19 pandemic were the unfortunate reports of doctors and nurses across parts of India being subjected to violence, harassment, and intimidation by suspected Covid-19 patients objecting to their forced hospital-based isolation and testing, which had no prior precedent $(49,50)$. In this situation, the HCWs themselves acted as tools of state coercion by treating reluctant patients at risk of transmitting infection during a pandemic. Subsequently, to stop attacks on healthcare providers, the central government promulgated an ordinance amending the Epidemic Diseases Act, 1897, enacting strict punishment for any person inflicting violence upon health workers. The decision while signifying responsiveness and solidarity failed to demonstrate trust among all the stakeholders (51).

During the pandemic, the extensive disruption of medical training programs and uncertainty and apprehensions over future careers contributed to significant anxiety, stress and burnout among young doctors at the frontline of Covid-19 patient management $(52,53)$. In this context, ensuring reciprocity through a transparent academic model for restoring teaching and training is highly desirable.

\section{(v) The ethics of health versus economics}

Early in the pandemic, governments worldwide, with few exceptions, assumed a dichotomy in protecting lives by implementing a lockdown order as opposed to preserving the economy. Proponents of the lockdown argued that millions of lives would be lost in the quest to achieve natural herd immunity otherwise, and valuable time to strengthen health preparedness would be rendered available through such a move (54). Also, a herd immunity approach had the real risk of overwhelming public health facilities in resourceconstrained settings (55).

Those opposed cited the long-term grave economic consequences of a lockdown translating into hunger, malnutrition, unemployment, and adverse mental health conditions (56). To date, evidence of the effectiveness of non-pharmaceutical interventions in controlling Covid-19 is mixed. Contrasting examples are that of New Zealand which implemented a stringent but brief lockdown during which importation and local transmission of Covid-19 cases were significantly reduced at the expense of an unprecedented economic contraction (57); and, Sweden, one of the only countries in the European Union to have a relaxed strategy for pandemic control by avoiding a lockdown and without masking regulations while still achieving some success in controlling the pandemic (58). However, the WHO at the beginning of the pandemic, recommended sustaining lockdowns for flattening the infection curve (59).

Working with such meagre and uncertain evidence had meant that any critical preliminary ethical inquiry could be subject to the precautionary principle, which would tend to favour a risk-averse solution promoting inaction (lockdown) over action (opening of the economy) (60). Consequently, any government decisions to enforce a lockdown during the pandemic cannot be considered as ethically invalid through contrary evidence obtained at a later date. However, the characteristics of the lockdown including the timing (if delayed allowing disease spread), duration (too short or too long), the effectiveness of implementation (lax or stringent), and measures that were taken for the protection of the most vulnerable populations (financial and material aid) are subject to ethical assessment.

\section{(vi). Union and the states: synergy, populism and political competition}

India has a federal system of government through a constitutionally defined division of powers between the central and subnational governments comprising the state and local governments. The lack of consensus and synergy between the centre and states, especially when governed by opposition parties, invariably leads to challenges in implementing central government policies in the states.

During the Covid-19 pandemic, centre-state antagonism has reflected in the flawed implementation of several policy decisions. These include non-adherence to testing policies since some states have consistently reported high test positivity rates, the failure to implement lockdown effectively, and occasional inability to ensure relief and rehabilitation measures for the most vulnerable sections of society. Both the center and state governments made efforts to project superior performance in combating the pandemic 
Table 2. Summary of an ethical framework for COVID-19 in India

\begin{tabular}{|c|c|c|c|c|c|c|}
\hline \multirow[t]{2}{*}{ Ethical domain } & \multirow{2}{*}{$\begin{array}{l}\text { Ethical } \\
\text { considerations/ } \\
\text { causes }\end{array}$} & \multirow{2}{*}{$\begin{array}{l}\text { Public health } \\
\text { response(s) }\end{array}$} & \multicolumn{2}{|l|}{ Values upheld } & \multicolumn{2}{|l|}{ Values threatened } \\
\hline & & & Substantial & Procedural & Substantial & Procedural \\
\hline $\begin{array}{l}\text { Allocation of } \\
\text { resources } \\
\text { 1. Testing } \\
\text { 2. Triage }\end{array}$ & $\begin{array}{l}\text { Expansion } \\
\text { Adequacy } \\
\text { Affordability } \\
\text { Individual } \\
\text { prioritisation (social } \\
\text { worth/family size) }\end{array}$ & $\begin{array}{l}\text { Graded expansion } \\
\text { Integration with } \\
\text { NHPS Delayed sero } \\
\text { prevalence } \\
\text { Dedicated Covid-19 } \\
\text { hospitals }\end{array}$ & $\begin{array}{l}\text { Equity Trust } \\
\text { Protection of the } \\
\text { public from harm }\end{array}$ & $\begin{array}{l}\text { Inclusive } \\
\text { Responsive Reason- } \\
\text { able } \\
\text { Responsive? } \\
\text { Proportionality }\end{array}$ & $\begin{array}{l}\text { Stewardship } \\
\text { Stewardship } \\
\text { Trust Equity Duty to } \\
\text { provide care }\end{array}$ & $\begin{array}{l}\text { Transparent and } \\
\text { openness } \\
\text { Accountability } \\
\text { Reasonable } \\
\text { Inclusive }\end{array}$ \\
\hline $\begin{array}{l}\text { Maintaining } \\
\text { essential services } \\
\text { 1. NCDs } \\
\text { 2.Maternal and } \\
\text { child health } \\
\text { 3. Emergency care }\end{array}$ & $\begin{array}{l}\text { Medication non- } \\
\text { adherence, non- } \\
\text { persistence } \\
\text { Missed Antenatal } \\
\text { care and } \\
\text { immunization } \\
\text { services } \\
\text { Challenges in } \\
\text { accessing } \\
\text { emergency care }\end{array}$ & $\begin{array}{l}\text { Longer refills } \\
\text { Telemedicine }\end{array}$ & Solidarity & $\begin{array}{l}\text { Reasonable } \\
\text { Proportionality }\end{array}$ & $\begin{array}{l}\text { Stewardship } \\
\text { Equity Do no harm } \\
\text { Reciprocity Duty to } \\
\text { provide care } \\
\text { Do no harm } \\
\text { Duty to provide } \\
\text { care Trust }\end{array}$ & $\begin{array}{l}\text { Inclusiveness } \\
\text { Responsiveness Ac- } \\
\text { countability } \\
\text { Reasonable } \\
\text { Accountability }\end{array}$ \\
\hline Coercive measures & $\begin{array}{l}\text { Mandatory testing } \\
\text { of contacts } \\
\text { Mandatory } \\
\text { hospitalisation of } \\
\text { suspected Covid-19 } \\
\text { Adherence to } \\
\text { lockdown and } \\
\text { containment }\end{array}$ & $\begin{array}{l}\text { Legal and police } \\
\text { action }\end{array}$ & $\begin{array}{l}\text { ?Stewardship } \\
\text { Protection of the } \\
\text { public from harm }\end{array}$ & Responsive & $\begin{array}{l}\text { Individual liberty } \\
\text { Privacy }\end{array}$ & $\begin{array}{l}\text { Reasonable } \\
\text { Proportionality }\end{array}$ \\
\hline $\begin{array}{l}\text { HCWs obligation to } \\
\text { treat }\end{array}$ & $\begin{array}{l}\text { Inadequate PPE } \\
\text { Violence }\end{array}$ & $\begin{array}{l}\text { Provision of PPE } \\
\text { based on risk } \\
\text { assessment } \\
\text { Enactment of } \\
\text { punitive legislation }\end{array}$ & $\begin{array}{l}\text { ?Equity } \\
\text { ? Solidarity? } \\
\text { Reciprocity? } \\
\text { Stewardship }\end{array}$ & $\begin{array}{l}\text { Responsive } \\
\text { Responsive }\end{array}$ & $\begin{array}{l}\text { ? Reciprocity Trust } \\
\text { ?Trust }\end{array}$ & $\begin{array}{l}\text { ? Accountability } \\
\text { ? Accountability }\end{array}$ \\
\hline $\begin{array}{l}\text { Health versus } \\
\text { economics }\end{array}$ & $\begin{array}{l}\text { Unemployment } \\
\text { and hunger in } \\
\text { impoverished } \\
\text { populations } \\
\text { Adequacy of relief } \\
\text { measures for } \\
\text { vulnerable migrant } \\
\text { labour } \\
\text { Mental health } \\
\text { problems }\end{array}$ & $\begin{array}{l}\text { Unemployment } \\
\text { and hunger in } \\
\text { impoverished } \\
\text { populations } \\
\text { Adequacy of relief } \\
\text { measures for } \\
\text { vulnerable migrant } \\
\text { labour } \\
\text { Mental health } \\
\text { problems }\end{array}$ & Solidarity & $\begin{array}{l}\text { Responsive } \\
\text { Stewardship } \\
\text { Responsive }\end{array}$ & $\begin{array}{l}\text { ?Equity } \\
\text { ?nclusiveness }\end{array}$ & $\begin{array}{l}\text { Transparent and } \\
\text { openness } \\
\text { Accountability }\end{array}$ \\
\hline $\begin{array}{l}\text { Prioritisation of } \\
\text { clinical and public } \\
\text { health research }\end{array}$ & $\begin{array}{l}\text { Challenge studies } \\
\text { Drug repurposing } \\
\text { Vaccine and drug } \\
\text { trials }\end{array}$ & $\begin{array}{l}\text { Criterion adherence } \\
\text { Timely reporting of } \\
\text { positive and } \\
\text { negative results, } \\
\text { adverse effects }\end{array}$ & Stewardship & & $\begin{array}{l}\text { Individual liberty } \\
\text { Do no harm Trust }\end{array}$ & ?Accountability \\
\hline
\end{tabular}


and winning public opinion in their favor. However, the necessity of synergy, partnerships and the willingness for learning and adapting from each other's best practices lacked prioritization due to unresolved conflicts between the various actors. Nevertheless, there were exceptions like the replication of the model involved in the successful contact tracing operations in Dharavi, Mumbai, Asia's largest slum cluster (61), and adoption of the home-isolation strategy for mild cases initiated in Delhi (62).

One example of this centre-state divide resulting in an avoidable escalation of hardships and suffering of the socioeconomically disadvantaged citizens and a denial of justice was evident during the migrant crisis occurring early during the lockdown. The central government was initially reluctant to facilitate the transport of migrant workers during the lockdown period to prevent transmission of the infection to the country's rural interiors. Moreover, it expected the state governments to provide food and shelter to the migrants during the lockdown, but the latter expressed their inhibitions for lack of resources. However, the decision to withhold inter-state transport caused millions of these workers to traverse on foot to reach their homes resulting in several deaths from accidents and exhaustion (63). The central government ultimately provided over 1000 special Shramik railway trains for transferring nearly 10 million migrant workers across the country during the lockdown. However, there were controversies, including overcharging of the migrants for ticket fares. The railways expected the state government to pay the already highly subsidised fares on behalf of the migrants. In contrast, states demanded the centre waive the fares altogether, and ultimately in several cases, the migrants had to pay the fare themselves (64). There was also resistance from individual states who allegedly delayed providing consent for running the trains, questioning the overall stewardship during a critical juncture (65).

\section{(vii). Ethical practices for upholding public health during a pandemic: non-government stakeholders}

The code of public health ethics is an obligation for abiding with public health principles by those having been vested by governments and society for implementing public health agendas (66). During a pandemic, the responsibility for upholding public health ethics should devolve on a broader range of stakeholders, including those involved directly or indirectly in delivering patient care (both government and private healthcare workers, hospital administrators, auxiliary and ancillary health workers).

There were several reports of the exploitation of patients through exorbitant overcharging in certain private hospitals during the Covid-19 pandemic (67). Similarly, ambulances charges were often highly inflated, compelling the Supreme Court to intervene and issue directions to the states to make these services available at affordable rates for those requiring them (68). These incidents reflect ethical and moral failings of: (a) individuals entrusted with public health responsibility engaged in either direct corruption or turning a blind eye to misdeeds (b) possible failure to maintain effective oversight and ensure accountability. The substantive ethical view highlights a dereliction of the duty to provide care, a breach of trust of the vulnerable patients and their families who reposed trust in the health system, and the subversion of justice, resulting from failure to act judiciously through the transparent utilisation of the available resources. In this context, the media is also a pivotal stakeholder with responsibilities for accurately and objectivity reporting the pandemic related information that is not in any way subject to government interference. Future content studies on media reporting during the Covid-19 pandemic should explore these aspects.

\section{Conclusion}

The management of the Covid-19 pandemic raises several searching questions related to biomedical ethics, which need to be critically debated (Table 2). In the absence of decisive evidence built on expert consensus for pandemic control, the Indian government adhered to the expert opinion to preclude any significant moral or ethical lapses in judgment. Consequently, these approaches were mostly devoid of risk-taking, occasionally reactive, and primarily reliant on the global experience for adopting best practices subject to economic and technological feasibility. However, there was a lack of policy impetus in venturing towards a systematic ethical exploration for resolving the ethical dilemmas pertaining to resource allocation in a complex socio-cultural environment with a fragile health system.

There is a moral imperative for practitioners of medical ethics in India to evolve a comprehensive ethical framework for guidance during pandemics that ventures into Indiaspecific challenges. These include:

- Identification of best practices for pandemic preparedness and response to preserve and promote public health; but tempered by the resource constraints and suboptimal social determinants of health, which inhibits their perfect replication in Indian social and health settings. In this regard, health system strengthening and capacity building of adequate medical infrastructure is an unfulfilled ethical imperative (69).

- Novel approaches to triage and allocation of scarce healthcare resources that recognize the limitations of transplanting developed world models in the Indian context considering the socioeconomic and cultural diversity,

- Ethical appropriateness of coercive and illiberal measures especially when applied among the socioeconomically disadvantaged and marginalized populations to contain the spread of disease, and 
- Recognition of the role of vital individual stakeholders involved in the implementation and delivery of government-sponsored policy during a pandemic, the ethical validity of whose personal conduct often determines the outcomes related to health, survival, and well-being of the dependent population.

\section{Conflicts of interest and funding: None declared}

Acknowledgments: We would like to thank the two peer reviewers whose insightful and critical comments greatly contributed towards improving the manuscript.

\section{References}

1. Ministry of Health and Family Welfare, Govt of India. Covid-19 India. As on May 18, 2020[cited 2020 May 18] Available from: https:// www.mohfw.gov.in/

2. Murhekar MV, Bhatnagar T, Selvaraju S, Rade K, Saravanakumar V, Thangaraj JWV, et al. Prevalence of SARS-CoV-2 infection in India: Findings from the national serosurvey, May-June 2020. Indian J Med Res. 2020;152(1 \& 2):48-60.

3. Central Bureau of Health Intelligence. National Health Profile. 2019 [cited 2020 Oct 18] Available from: www.cbhidghs.nic.in/ showfile.php?lid=1147

4. British Medical Association. COVID-19 Ethical Issues: A guidance note. 2020[cited 2020 Oct 18] Available from: https:// www.bma.org.uk/media/2226/bma-covid-19-ethics-guidance.pdf

5. Mathur R. Ethics preparedness for infectious disease outbreaks research in India: A case for novel coronavirus disease 2019. Indian J Med Res. 2020;151:124-31.Doi: 10.4103/ijmr.IJMR_463_20

6. Saxena A, Horby P, Amuasi J, Aagaard N, Kohler J, Gooshki ES. et al. Ethics preparedness: facilitating ethics review during outbreaks recommendations from an expert panel. BMC Med Ethics. 2019 May 6;20:29.Doi: 10.1186/s12910-019-0366-x

7. Joint Center for Bioethics Pandemic Influenza Working Group. Stand on Guard for Thee: Ethical considerations in preparedness planning for pandemic influenza. Toronto: University of Toronto; 2005 Nov [cited 2020 May 18]. Available from: https://www.deslibris.ca/en-US/ Read.aspx?ID $=2367$

8. Reid L. Triage of critical care resources in COVID-19: a stronger role for justice. J Med Ethics. 2020;46(8):526-530. Doi:10.1136/medethics2020-106320

9. Acharya R, Porwal A. A vulnerability index for the management of and response to the COVID-19 epidemic in India: an ecological study. Lancet Glob Health. 2020;S2214-109X(20)30300-4. Doi:10.1016/ S2214-109X(20)30300-4.

10. Marckmann G, Schmidt H, Sofaer N, Strech D. Putting public health ethics into practice: a systematic framework. Front Public Health. 2015;3:23. Doi:10.3389/fpubh.2015.00023

11. Xafis V, Schaefer GO, Labude MK, Brassington I, Ballantyne A, Lim HY, et al. An Ethics Framework for Big Data in Health and Research. Asian Bioeth Rev. 2019;11,227:54.

12. Dawson, A., Jennings, B. The Place of Solidarity in Public Health Ethics. Public Health Rev. 2012; 4:34. Doi: 10.1007/BF03391656.

13. Upshur REG. Principles for the justification of public health interventions. Can J Public Health. 2002; 93:101-3.

14. Holtug N. The Harm Principle. Ethic Theory Moral Prac. 2002:5;357-89

15. Fauci AS, Lane HC, Redfield RR. Covid-19 - Navigating the Uncharted. N Engl J Med. 2020;382(13):1268-9. Doi: 10.1056/ NEJMe2002387.

16. Perappadan BS. COVID -19 | Testing, treatment now available for free under Ayushman Bharat Scheme. Hindu 2020 Apr 5[cited 2020 May 17]. Available from: www.thehindu.com/news/national/coronavirustesting-treatment-now-available-for-free-under-ayushman-bharatscheme/article31261580.ece]

17. ANI. With 828 tests/day per million population, India exceeds WHO advisory on COVID-19 testing by almost six times [cited 2020 October 18]. Available from: https://economictimes.indiatimes.com/ news/politics-and-nation/with-828-tests/day-per-millionpopulation-india-exceeds-who-advisory-on-covid-19-testing-byalmost-six-times/articleshow/78485304.cms

18. World Health Organisation. Public health criteria to adjust public health and social measures in the context of COVID-19. Annex to Considerations in adjusting public health and social measures in the context of COVID-19. Geneva: WHO; 2020 May 12[cited 2020 October 18].Availablefrom:https://apps.who.int/iris/bitstream/
handle/10665/332073/WHO-2019-nCoV-Adjusting PH measuresCriteria-2020.1-eng.pdf?sequence $=1$ \&isAllowed=yMay

19. Sheriff MK. Centre tells states: Do RT-PCR to catch false negatives after rapid antigen test. Indian Express. 2020 September 11[Cited 2020 October 18]. Available from: https://indianexpress.com/article/ india/centre-tells-states-do-rt-pcr-to-catch-false-negatives-afterrapid-antigen-test-6591294/

20. van Bogaert DK, Ogunbanjo GA. The Quandaries of the Principle of Triage. South African Family Practice. 2005;47:2:47-9.

21. Truog RD, Mitchell C, Daley GQ. The Toughest Triage - Allocating Ventilators in a Pandemic. N Engl J Med. 2020. Doi: 10.1056/ NEJMp2005689.

22. World Bank. Hospital beds per 1000 population. [cited 2020 May 17] Available from: https://data.worldbank.org/indicator/ SH.MED.BEDS.ZS

23. Singh P, Shamika R, Chakraborty S. COVID-19 | "Is India's health infrastructure equipped to handle an epidemic?" Brookings.edu. 2020 Mar 24[cited 2020 May 17] Available from: www.brookings.edu/blog/up-front/2020/03/24/is-indias-healthinfrastructure-equipped-to-handle-an-epidemic/

24. Press Information Bureau. 50,000 Made in India Ventilators under PM CARES Fund to fight COVID-19. 2020 Jun 23 [cited 2020 October 18] Available from: https://pib.gov.in/PressReleasePage.aspx? $\mathrm{PRID}=1633516$

25. Jebaraj P. Ventilators from firms funded by PM CARES fail trials. Hindu. 2020 Aug 21 [cited 2020 Oct 18] Available from: https:// www.thehindu.com/news/national/coronavirus-ventilators-fromfirms-funded-by-pm-cares-fail-trials/ article32416810.ece\#: :text=The\%20PM\%20CARES\%20fund\%20an nounced, $19 \% 20$ cases $\% 20$ across $\% 20$ the $\% 20$ country\%E2\%80\%9D.

26. Jöbges S, Vinay R, Luyckx VA, Biller-Andorno N. Recommendations on COVID-19 triage: international comparison and ethical analysis. Bioethics. 2020;00:1-12

27. Cash R, Patel V. Has COVID-19 subverted global health? Lancet. 2020 Doi: 10.20529/IJME.2020.041

28. Ghosal S, Sinha B, Majumder M, Misra A. Estimation of effects of nationwide lockdown for containing coronavirus infection on worsening of glycosylated haemoglobin and increase in diabetesrelated complications: A simulation model using multivariate regression analysis. Diabetes Metab Syndr. 2020;14(4):319-23. Doi: 10.1016/j.dsx.2020.03.014.

29. COVIDSurg Collaborative, Nepogodiev D, Bhangu A. Elective surgery cancellations due to the COVID-19 pandemic: global predictive modelling to inform surgical recovery plans. Br J Surg. 2020 Oct; 107(11):1440-9. Doi: 10.1002/bjs.11746.

30. Garg S, Basu S, Rustagi R, Borle A. Primary Health Care Facility Preparedness for Outpatient Service Provision During the COVID-19 Pandemic in India: Cross-Sectional Study. JMIR Public Health Surveill. 2020 Jun 1;6(2):e19927. Doi: 10.2196/19927.

31. Behera D. TB control in India in the COVID era. Indian J Tuberc. 2020 Jan; 68(1):128-133. Doi: 10.1016/j.ijtb.2020.08.019

32. Basu S. Non-communicable disease management in vulnerable patients during Covid-19. Indian J Med Ethics. 2020;V(2):103-5. Doi: 10.20529/IJME.2020.041

33. Trivedi M, Shingada A, Shah M, Khanna U,Karnik ND, Ramachandran R. The impact of covid 19 on maintenance haemodialysis patients: The Indian scenario. Nephrology. 2020 Jul 26;25(12):929-32. Doi: $10.1111 /$ nep.13760

34. World Health Organization. Regional Office for the Western Pacific. (2020). Routine immunization services during the COVID-19 pandemic. Manila:WHO Regional Office for the Western Pacific. 2020 Apr 24[cited 2020 Oct 18] Available from: https://apps.who.int/iris/ handle/10665/331925

35. Sarfaraz K. Covid-19 impact: Menstrual hygiene worsens for girls in capital's slums. Hindustan Times. 2020 Oct 1 [cited 2020 Oct 18]. Available from: https://www.hindustantimes.com/delhi-news/covid19-impact-menstrual-hygiene-worsens-for-girls-in-capital-s-slums/ story-z8G0IISx9CMbknK9fb4sKO.html

36. KPMG. Response to COVID-19 by the Anganwadi ecyosystem in India. 2020. [Cited 2020 Oct 18] Available from: https://home.kpmg/ content/dam/kpmg/in/pdf/2020/06/anganwadi-report-2020.pdf

37. Kass NE. An ethics framework for public health. Am J Public Health. 2001;91(11):1776-82.

38. WHO. Report of the WHO-China Joint Mission on Coronavirus Disease 2019 (COVID-19). Feb 2020. [Cited 2020 May 17] Available from: https://www.who.int/docs/default-source/coronaviruse/whochina-joint-mission-on-covid-19-final-report.pdf

39. Tharoor I. Coronavirus kills its first democracy. Washington Post. 2020 March 31. [Cited 2020 May 17] Available from: 
www.washingtonpost.com/world/2020/03/31/coronavirus-kills-itsfirst-democracy

40. Pandey A. Coronavirus in India: Man stamped for quarantine in Mumbai caught at Secundarabad railway station. India Today. 2020 Feb 22[cited 2020 May17]. Available from: https:// www.indiatoday.in/india/story/coronavirus-in-india-stamped-inmumbai-youth-caught-by-authorities-at-secunderabad-railwaystation-1658366-2020-03-22

41. Jaiswal PB. Privacy of COVID-19 suspects violated; names, addresses made public. Week. 2020 Mar 22 [cited 2020 May 17]. Available from: www.theweek.in/news/india/2020/03/22/privacy-of-covid-19suspects-violated-names-addresses-made-public.html

42. Coronavirus: 30 Islamic Sect Members, Including Allahabad Professor Arrested, Says UP Police. Press Trust of India. 2020 Apr 21 [cited 2020 May 17] Available from: www.ndtv.com/allahabad-news/ coronavirus-30-tablighi-jamaat-members-including-allahabadprofessor-arrested-says-up-police-2215851

43. Press Trust of India. Bihar: Four cops injured in attack by group owing allegiance to Tablighi Jamaat, police say [cited 2020 October 18] Available from: https://www.outlookindia.com/newsscroll/ bihar-four-cops-injured-in-attack-by-group-owing-allegiance-totablighi-jamaat-police-say/1788015

44. Gopichandran V. Clinical ethics during the Covid-19 pandemic: Missing the trees for the forest. Indian J Med Ethics. 2020 Jul-Sep;5(3): 182-7.DOI:10.20529/IJME.2020.053

45. Schuklenk Udo. Health Care Professionals Are under No Ethical Obligation to Treat COVID-19 Patients. Blog. J Med Ethics. 2020 Apr 1 [cited 2020 Oct18] Available from: https://blogs.bmj.com/medicalethics/2020/04/01/health-care-professionals-are-under-no-ethicalobligation-to-treat-covid-19-patients/

46. World Health Organization. Advice on the use of masks in the community, during home care and in healthcare settings in the context of the novel coronavirus (COVID-19) outbreak. Geneva: WHO; 2020 Mar 19[cited 2020 Oct 18]. Available from: WHO/2019nCoV/IPC_Masks/2020.2

47. Hermerén G. The principle of proportionality revisited: interpretations and applications. Med Health Care Philos. 2012;15(4): 373-82. Doi: 10.1007/s11019-011-9360-x.

48. PTI. India donates 1.8 million N95 masks to American city of Philadelphia following mayor's plea. Economic Times. 2020 Oct 10 [cited 2020 Oct 18]. Available from: https:// economictimes.indiatimes.com/news/politics-and-nation/indiadonates-1-8-million-n95-masks-to-american-city-of-philadelphiafollowing-mayors-plea/articleshow/78586124.cms? utm_source=contentofinterest\&utm_medium=text\&utm_campaig $\mathrm{n}=\mathrm{cppst}$

49. HT Correspondent. Jamaat members resisting testing, hospitalisation, complains Delhi hospital" Hindustan Times. 2020 Apr 2 [cited 2020 May 18]. Available from: www.hindustantimes.com/ india-news/jamaat-members-resisting-testing-hospitalisationcomplains-delhi-hospital/story-2XEDL38NHvKp2rdpAktMHP.html

50. Anand T, Grover S, Kumar R, Kumar M, Ingle GK. Workplace violence against resident doctors in a tertiary care hospital in Delhi. Natl Med J India 2016;29:344-8.

51. Government of India. Promulgation of an Ordinance to amend the Epidemic Diseases Act, 1897 in the light of the pandemic situation of COVID-19" Press Information Bureau. 2020 Apr 22 [cited 2020 May 17] Available from:https://pib.gov.in/newsite/PrintRelease.aspx? relid=202493

52. Choi B, Jegatheeswaran L, Minocha A, Alhilani M, Nakhoul M, Mutengesa $\mathrm{E}$, et al. The impact of the COVID-19 pandemic on final year medical students in the United Kingdom: a national survey. BMC Med Educ. 2020;20:206. Doi: 10.1186/s12909-020-02117-1

53. Saxena A. Delhi: Lok Nayak a Covid facility, MAMC docs say 'training, clinical services at a halt'. Indian Express. 2020 Oct 13[cited 2020 Oct 18]. Available from: https://indianexpress.com/article/cities/delhi/ lok-nayak-a-covid-facility-mamc-docs-say-training-clinical-servicesat-a-halt-6722600/

54. Dowdy D, D'Souza G. Early Herd Immunity against COVID-19: A Dangerous Misconception. JHU: Coronavirus Resource Center. Date unknown [cited 2020 May 17] Available from: https:// coronavirus.jhu.edu/from-our-experts/early-herd-immunityagainst-covid-19-a-dangerous-misconception

55. Ramachandran R. COVID-19-a very visible pandemic. Lancet. 2020 Aug 8;396(10248):e13-4. Doi: 10.1016/S0140-6736(20)31673-1

56. Bhattacharya J. Packalen M. Lives vs lives - the global cost of lockdown: Policies that depress the world economy put millions at risk. Spectator. 2020 May 16 [cited 2020 May 17]. Available from: https://www.spectator.co.uk/article/lives-vs-lives-the-global-costof-lockdown

57. Robert A. Lessons from New Zealand's COVID-19 outbreak response. Lancet Pub Health. 2020 Nov;5(11):e569-70. Doi: 10.1016/S24682667(20)30237-1

58. Giesecke J. The invisible pandemic. Lancet. 2020 May 30;395(10238):e98. Doi: 10.1016/S0140-6736(20)31035-7.

59. 'Deadly resurgence' if curbs lifted too early, WHO warns". BBC. 2020 Apr 10 [cited 2020 May 17]. Available from: www.bbc.com/news/ world-52248516

60. Goldstein BD. The precautionary principle also applies to public health actions. Am J Public Health. 2001;91(9):1358-61.

61. Golechha M. COVID-19 Containment in Asia's Largest Urban Slum Dharavi-Mumbai, India: Lessons for Policymakers Globally. J Urban Health. 2020;1-6. Doi:10.1007/s11524-020-00474-2.

62. Home isolation helped over 50 per cent COVID-19 patients recover in Delhi. New Indian Express. 2020 September 20 [Cited 2020 October 18] Available from: https://www.newindianexpress.com/ cities/delhi/2020/sep/26/home-isolation-helped-over-50-percentcovid-19-patients-recover-in-delhi-2202105.html

63. Iyer M. Migration in India and the impact of the lockdown on migrants. PRS Legislative Research. 2020 June 16 [cited 2020 October 18] Available from: https://www.prsindia.org/theprsblog/migrationindia-and-impact-lockdown-migrants

64. Dutta A. Railways earned Rs 430 crore from Shramik Special train fares. Hindustan Times. 2020 June 24 [Cited 2020 October 18] Available from: https://www.hindustantimes.com/india-news/ railways-earned-rs-430-crore-from-shramik-special-train-fares/ story-duFiaV9EILYEkbF4NpLiDK.htm

65. Dutta A. Shramik Specials: Consent of receiving states no longer required. Hindustan Times. [Cited 2020 May 19]. Available from: https://www.hindustantimes.com/india-news/shramik-specialsconsent-of-receiving-states-no-longer-required/storyJghHpmgSsIVCSZe92ujqvM.htm

66. Thomas JC, Sage M, Dillenberg J, Guillory VJ. A code of ethics for public health. Am J Public Health. 2002 Jul;92(7):1057-9.

67. Dash S. Despite Delhi govt capping COVID-19 treatment prices, complaints of private hospitals overcharging persist. Firstpost. 2020 Aug 9 [cited 2020 Oct 18] Available from: https://www.firstpost.com/ health/month-after-delhi-govt-caps-covid-19-treatment-pricespatients-complain-of-overcharging-by-private-hospitals8686401.html

68. Covid-19: SC directs states to fix reasonable price for ambulance services. Livemint. 2020 Sep 11 [cited 2020 Oct 18] Available from: https://www.livemint.com/news/india/covid-19-sc-directs-statesto-fix-reasonable-price-for-ambulance-services11599825260824.html

69. Gopichandran V, Subramaniam S. Response to Covid-19: An ethical imperative to build a resilient health system in India. Indian J Med Ethics. 2020;5(2):1-4. Doi: 10.20529/IJME.2020.026. 